Biol. Stud. 2012: 6(3); 115-124 • DOI: https://doi.org/10.30970/sbi.0603.243

www.http://publications.Inu.edu.ua/journals/index.php/biology

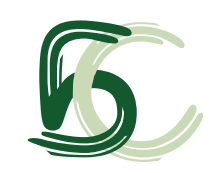

UDC: $579.846 .2: 22$

\title{
GROWTH OF VARIOUS STRAINS OF SULFATE-REDUCING BACTERIA OF HUMAN LARGE INTESTINE
}

\author{
I. V. Kushkevych ${ }^{1}$, O. M. Moroz ${ }^{2}$ \\ ${ }^{1}$ Danylo Halytsky Lviv National Medical University, 69, Pekarska St., Lviv 79010, Ukraine \\ 2/van Franko National University of Lviv, 4, Hrushevskyi St., Lviv 79005, Ukraine \\ e-mail: ivan.kushkevych@gmail.com
}

New strains of sulfate-reducing bacteria were obtained from human intestine. These bacteria are vibrio-like (strains SRB Vib-1, SRB Vib-2, SRB Vib-3) and short rod-like (strains SRB Rod-4 and SRB Rod-5) forms. Growth of these strains of bacteria, usage of sulfates by bacteria and their production of hydrogen sulfide were studied. The strains of sulfate-reducing bacteria SRB Vib-1, SRB Vib-2, SRB Vib-3 more intensively accumulate biomass compared with strains SRB Rod-4 i SRB Rod-5. The SRB Vib-1 and SRB Vib-2 strains grow most intensively. Accumulation of bacterial biomass $(3.8 \mathrm{~g} / \mathrm{l})$ is the highest on the third day of cultivation, and after that a stationary growth phase began. The SRB Vib-3 strain of bacteria accumulates 2.89 gram per liter of biomass on the third day of bacteria cultivation. Maximal biomass of SRB Rod-4 and SRB Rod-5 bacteria strains ranged from 2.59 to 3.25 gram per liter on the eighth day of cultivation. The obtained sulfate-reducing bacteria intensively use sulfate ions and produce hydrogen sulfide. The SRB Vib-1, SRB Vib-2, SRB Vib-3 strains produce from $2.99 \mathrm{mM}$ to 3.12 $\mathrm{mM}$ of hydrogen sulfide. The rod-shaped strains of sulfate-reducing bacteria use sulfate ions and produce hydrogen sulfide less intensively in the presence of sulfates.

Keywords: sulfate-reducing bacteria, Desulfovibrio, Desulfomicrobium, sulfates, hydrogen sulfide, bowel diseases, ulcerative colitis, intestinal microbiocenosis.

\section{INTRODUCTION}

Sulfate-reducing bacteria belong to normal intestinal flora in human [2, 5]. The number of these microorganisms depends on the composition and quality of the food consumed by human $[3,6,7,12]$. An excessive use of sulfates in diet leads to an increase in number of sulfate-reducing bacteria (SRB). Dissimilatory sulfate reduction by the SRB and the formation of hydrogen sulfide in the intestinal lumen can cause a variety of inflammatory processes [3, 5, 13].

Ulcerative colitis is one of the most common acute inflammatory human bowel diseases $[21,24,25,27]$. Active agents of the disease have not been profoundly studied. Perhaps, development of this disease depends on human nutrition, as well as the qualitative 
and quantitative composition of the intestinal microflora $[2,7,16]$. Active agents of the ulcerative colitis and inflammatory bowel may be sulfate-reducing bacteria. Different ratios and the number of sulfate-reducing bacteria were established in the intestinal microflora of people living in different geographical areas [7, 19, 25, 27].

It is very important to obtain new strains of the SRB from different people, identifying them, and studying their growth, physiological and biochemical properties, processes of dissimilatory sulfate reduction, and the production of hydrogen sulfide by these bacteria, to clarify the etiological role of these bacteria in pathogenesis of various diseases.

Studies on growth, dissimilatory sulfate reduction and the production of hydrogen sulfide by new strains of SRB, isolated from intestine of everyone, will help better understanding the mechanisms of sulfate reduction in human intestine of each individual, and also trophic interactions of these bacteria with other microorganisms of the intestine. Data on the number of hydrogen sulfide produced by the isolates is supposed to help in establishing and assessing a toxicity effect of hydrogen sulfide for epithelial cells of the human intestine, isolated by the bacteria. Such studies will help in predicting a possibility of nascence of disease. It will help to get more details of etiology of bowel disease. It is very important for clinical diagnosis of the diseases. Such studies are not conducted in Ukraine.

The aim of our research was to obtain the sulfate-reducing bacteria from colon feces healthy people, investigate growth of the obtained microorganisms, and study of dissimilatory sulfate reduction and production of hydrogen sulfide by these bacteria.

\section{MATERIALS AND METHODS}

The objects of our studies were isolates of sulfate-reducing bacteria obtained from feces of human large intestine at the Microbiology, Virology and Immunology Department of Danylo Halytsky Lviv National Medical University.

First task of our study was to obtain biological material from healthy human. One gram of feces was suspended in $9 \mathrm{ml}$ of liquid medium. Before, the medium was heated in boiling water for 30 min to obtain an oxygen-free medium, and cooled to $+25^{\circ} \mathrm{C}$ temperature. The collected material was then seeded into nutritional liquid medium of such composition (g/l) [10]: $\mathrm{Na}_{2} \mathrm{SO}_{4}-0.5 ; \mathrm{KH}_{2} \mathrm{PO}_{4}-0.3 ; \mathrm{K}_{2} \mathrm{HPO}_{4}-0.5 ;\left(\mathrm{NH}_{4}\right)_{2} \mathrm{SO}_{4}-0.2$; $\mathrm{NH}_{4} \mathrm{Cl}-1.0 ; \mathrm{CaCl}_{2} \times 6 \mathrm{H}_{2} \mathrm{O}-0.06 ; \mathrm{MgSO}_{4} \times 7 \mathrm{H}_{2} \mathrm{O}-0.1 ; \mathrm{C}_{3} \mathrm{H}_{5} \mathrm{O}_{3} \mathrm{Na}-2.0$; yeast extract 1.0; $\mathrm{FeSO}_{4} \times 7 \mathrm{H}_{2} \mathrm{O}-0.004$; sodium citrate $\times 2 \mathrm{H}_{2} \mathrm{O}-0.3$.

Before bacteria seeding in medium $10 \mathrm{ml} / \mathrm{l}$ of sterile More salt solution $\left[\left(\mathrm{NH}_{4}\right)\right.$ $\left.\mathrm{SO}_{4} \mathrm{Fe}\left(\mathrm{SO}_{4}\right)_{2} \times 6 \mathrm{H}_{2} \mathrm{O}\right](10 \%)$ and $0.05 \mathrm{ml} / /$ of sterile solution of $\mathrm{Na}_{2} \mathrm{~S} \times 9 \mathrm{H}_{2} \mathrm{O}(1 \%)$ were added. To provide $\mathrm{pH} 7.2$ of medium used sterile $10 \mathrm{~N}$ solution of $\mathrm{NaOH}(0.9 \mathrm{ml} / \mathrm{l})$. The bacteria were grown for 10 days at $+37^{\circ} \mathrm{C}$ under anaerobic conditions. The tube was brim-filled with medium and closed by rubber plug to provide anaerobic conditions.

In frames of the second task, we performed reseeding of received biomass onto Petri's plates with nutritional solid medium to obtaining pure culture. Anaerobic conditions were provided with usage of oxygen uptake generators which were placed in the anaerobic box. To be sure that the selected microorganisms belong to the sulfate-reducing bacteria, we selected large and small colonies from each Petri's plates and resuspended these colonies in sterile saline $(0.9 \%$ solution of $\mathrm{NaCl})$. After that, we reseeded the resuspended bacteria in the standard medium containing a sulfate (concentration $3.5 \mathrm{mM}$ ), and in the same medium without sulfate ions.

To determine an ability of the bacteria to sporulation, we selected two types of these colonies resuspended them in a liquid medium, and withstand at $+80^{\circ} \mathrm{C}$ for 10 min after thir seeding in the medium.

ISSN 1996-4536 • Біологічні Студії / Studia Biologica • 2012 • Том 6/№3 • С. 115-124 
We examined biomass accumulation by different strains of sulfate-reducing bacteria by photometric method (nutritional medium was without More salt) [4].

The sulfate ions and hydrogen sulphide concentrations were determined by the turbidymetric method [1, 11].

For electron microscopy studies, the bacterial cells were washed with $0.9 \% \mathrm{NaCl}$ and precipitated by centrifugation at $17696 \mathrm{~g}$ for $15 \mathrm{~min}$. Intact cells were fixed in $1.5 \%$ aqueous solution of $\mathrm{KMnO}_{4}$ at ambient temperature $\left(+20^{\circ} \mathrm{C}\right)$ for 20 min. Postfixation was performed using $1 \% \mathrm{OsO}_{4}$ in cacodylate buffer at $0^{\circ} \mathrm{C}$ for $90 \mathrm{~min}$. Fixed cells were washed, dehydrated in solutions with increasing concentrations of ethanol and propylene oxide. Samples were transferred in epoxy resin Epon 812. Ultrathin sections were done by ultramicrotome UMTP-6 and they were contrasted by lead citrate as described by Reynolds [23].

Photographs of the samples were taken under electronic transmission microscope UEMV-100B and PEM-100 at accelerating voltage of $75 \mathrm{kV}$. Final increase of the micrographs was $\times 15000$. Performance increase of the electron microscope was with an accuracy of $\pm 5 \%$.

Measuring of the cell size was performed on the positive reflected from the negative. Size increase and very small structures were measured on a larger footprint [26]. The marking lines were put on the positive, and the negative was retained for making additional prints. In parallel, measuring of the printout was performed, and possible errors in determining the photographed positive increase were taken into account. In the process of elaboration, the reflection may be slightly reduced in size (compressed). For measuring large objects (cells), an accurate gauge ruler graduated in $0.5 \mathrm{~mm}$ was used. For measuring small parts, we used special meter with magnifying glass and netting.

The basic statistic parameters $(M-$ arithmetic average, $m$ - standard error of the arythmetic average, $\mathrm{M} \pm \mathrm{m}$ ) were calculated using the experimental data. For estimation of the validity of difference between the statistical characteristics of the data, Student' index was calculated. The difference was valid when $P>0.95$ [14]. Statistical processing of the results was performed using Excel and Origin programs [9].

\section{RESULTS AND DISCUSSION}

The results of our study showed that the isolated colonies on solid nutrition medium with More salt were identical in shape (round), color (black), profile and structure. They differed only in size (large and small colonies) (Table 1).

\section{Table 1. The characteristics of obtained bacterial colonies}

\section{Таблиця 1 Характеристика колоній виділених бактерій}

\begin{tabular}{c|c|c|c|c|c}
\hline \multirow{2}{*}{ Colonies } & \multirow{2}{*}{$\begin{array}{c}\text { Gram staining } \\
\text { (positive/negative) }\end{array}$} & \multicolumn{4}{|c}{ Characteristics of colonies } \\
\cline { 3 - 6 } & Colour & Shape & Diameter, mm & $\begin{array}{c}\text { Spore } \\
\text { forming }\end{array}$ \\
\hline Large & Negative & Black & Round & 2 & Non \\
\hline Small & Negative & Black & Round & Up to 1 & Non \\
\hline
\end{tabular}

The selected resuspended bacterial colonies (large and small) were grown up only in the medium with sulfate ions (Fig. 1). The studied bacteria do not grow in the medium without sulfates. Due to the obtained results isolated strains belong to the sulfate-reducing bacteria. 
The growth of selected bacterial colonies was not observed in the nutritional medium after heating and seeding of the resuspended bacterial colonies. It helped to establish that any bacteria colony cells do not form spores (see Table 1). The cultivation of these microorganisms in anaerobic, microaerophilic and aerobic conditions showed that they are obligate (strict) anaerobes.

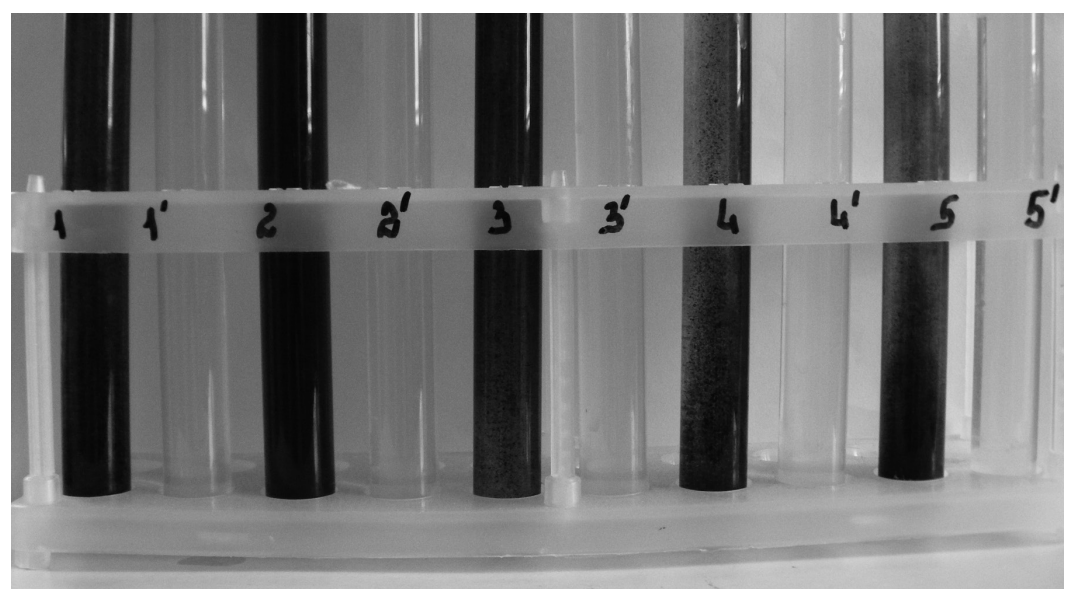

Fig. 1. Growth of different strains of sulfate-reducing bacteria in a liquid medium: $1,2,3,4,5$ - nutritional medium with sulfate-ions; $1^{\prime}, 2^{\prime}, 3^{\prime}, 4^{\prime}, 5^{\prime}$ - nutritional medium without sulfate-ions

Рис. 1. Ріст різних штамів сульфатвідновлювальних бактерій у рідкому середовищі: 1, 2, 3, 4, 5 - поживне середовище зі сульфат-іонами; 1', 2', 3', 4', 5' - поживне середовище без сульфат-іонів

Total number of the obtained SRB in feces was $10^{5}$ colony-forming units per gram of feces. 157 obtained colonies of microorganisms were examined under the light microscope. The microscopic study showed that bacterial preparations made of 124 large bacterial colonies contained active motile cells. The live bacterial preparations taken from 33 small colonies contain also motile cells. The cells of large colonies are vibrio form, and the cells of small colonies are short rods form on fixed preparations. The bacterial cells of both types of colonies are Gram-negative (see Table 1).

The results of electronic microscopic study helped to confirm that two types of isolated colonies of SRB contain morphologically different cells. Large isolated colonies contain vibrio-like cells, and other small colonies contain short rods cells. The size of the vibrio cells is $0.6-0.8 \times 2.7-3.5 \mu \mathrm{m}$. They are slightly curved with a crescent forms. The size of short rods cells is $0.5 \times 0.8-1.0 \mu \mathrm{m}$. They are similar to the coccobacilli forms (Fig. 2).

Similar strains of vibrios and short rods that distinguish from each other by the morphological, physiological and biochemical characteristics belonging to Desulfovibrio and Desulfomicrobium genera were obtained by G.R. Gibson et al $[5,6]$. They found that the genus Desulfovibrio is dominant SRB in the gut. The species of Desulfovibrio genus make up $67-91 \%$ of the total number of SRB [5-7]. The species of Desulfomicrobium genus are isolated also from the oral cavity during periodontal diseases in human [15]. The Desulfovibrio bacteria are colonizing the intestine; they are also capable of forming a biofilm and migrating within the biofilm mucosal layer of the colon [2, 18, 19].

ISSN 1996-4536 • Біологічні Студії / Studia Biologica • 2012 • Том 6/№3 • С. 115-124 


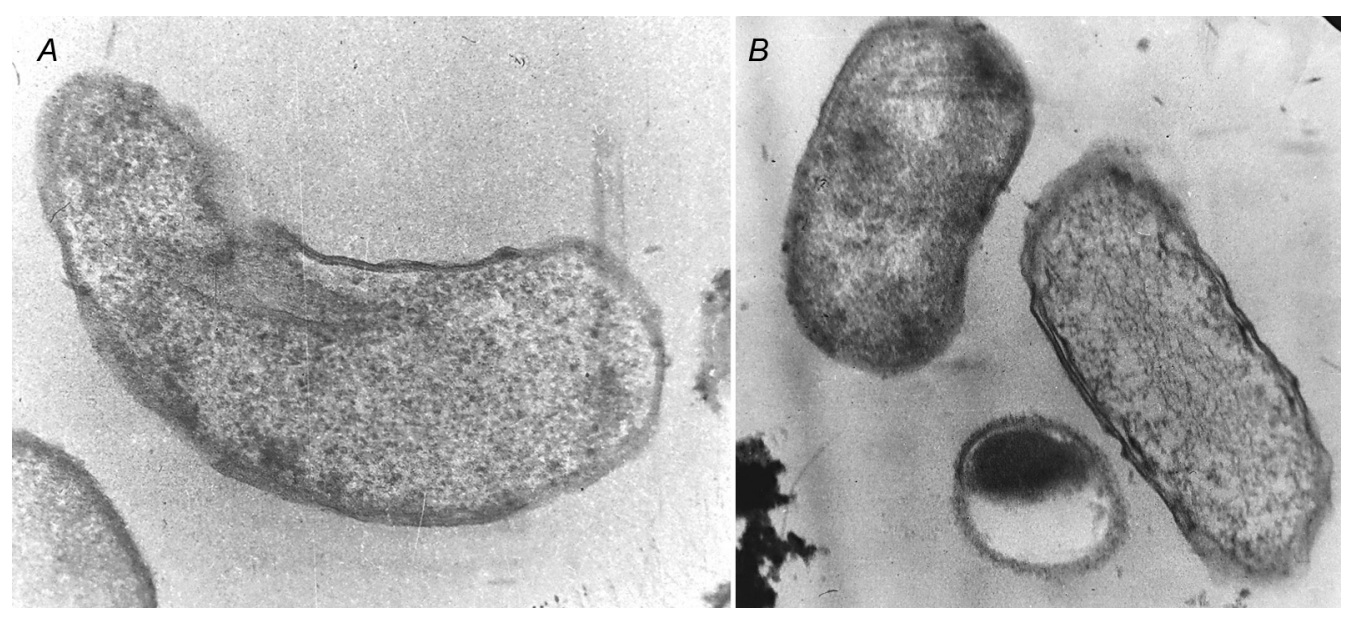

Fig. 2. Ultrastructure of sulfate-reducing bacteria cells (electron microscopy, $\times 15000$ ): $A-$ vibrios (strain SRB Vib-1); $B$ - short rods (strain SRB Rod-4)

Рис. 2. Ультраструктура клітин сульфатвідновлювальних бактерій (електронна мікроскопія, ×15 000): $A$ - вібріони (штам SRB Vib-1); B - короткі палички (штам SRB Rod-4)

The next task of our work was to investigate the growth of various SRB strains. Our study has shown that three selected strains of vibrios (SRB Vib-1, SRB Vib-2 and SRB Vib-3) accumulated almost equal biomass (Fig. 3A, B, C). The SRB Vib-1 and SRB Vib2 strains were growing most intensively. Accumulation of bacterial biomass $(3.82 \mathrm{~g} / \mathrm{l})$ was the highest on the third day of cultivation, and after that, the stationary growth phase was observed. The SRB Vib-3 strain grew a little bit less intensively, compared with SRB Vib-1 and SRB Vib-2 strains. The SRB Vib-3 strain of bacteria accumulated biomass equal $2.89 \mathrm{~g} / \mathrm{l}$ on the third day of cultivation, and after the fourth day, bacteria SRB Vib-3 strain was in the stationary phase of growth.

The growth of bacteria possessing short rod form (SRB Rod-4 and SRB Rod-5) differed from the vibrios-like microorganisms (see Fig. 3). The strains of bacteria SRB Rod-4 and SRB Rod- 5 are characterized by less intensive accumulation of the biomass. They were on the stationary phase of growth only to the sixth day of cultivation. Maximum biomass of these bacteria ranged from 2.88 to $3.25 \mathrm{~g} / \mathrm{l}$ on the eighth day of cultivation (see Fig. 3D, E).

In the processes of the dissimilatory sulfate reduction sulfate-reducing bacteria can reduce sulfate to hydrogen sulfide $[2,12]$. The sulfate ions are used by these microorganisms as electrons acceptors during sulfate respiration [8, 22]. So, the next task of our work was to investigate the processes of the dissimilatory sulfate reduction by studied bacteria.

As one can be seen from the results of our study the of bacteria SRB Vib-1 and SRB Vib-2 strains used $\mathrm{SO}_{4}^{2-}$ most rapidly and extensively. These strains (SRB Vib-1 and SRB Vib-2) used 80 and $76 \% \mathrm{SO}_{4}^{2-}$, respectively, from the medium on the second day compared with the initial concentration. The slowest was the usage of sulfate ions by SRB Vib-3 bacteria. On the second day they used only $58 \% \mathrm{SO}_{4}^{2-}$ compared with the initial concentration (see Fig. $3 A, B, C$ ). 
The SRB Rod-4 and SRB Rod-5 bacteria use sulfate ions less intensively, compared with SRB Vib-1, SRB Vib-2 and SRB Vib-3 strains (see Fig. 3D, E). On the second day of cultivation SRB Rod-4 and SRB Rod-5 bacteria used only 55 and $41 \%$ of sulfate ions, respectively.
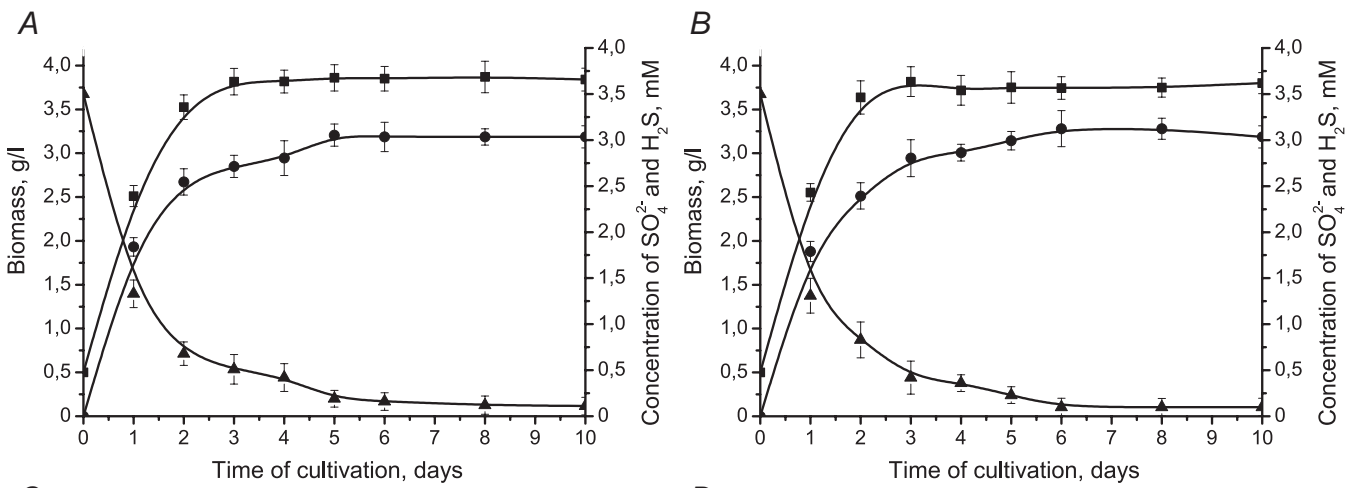

C

$D$
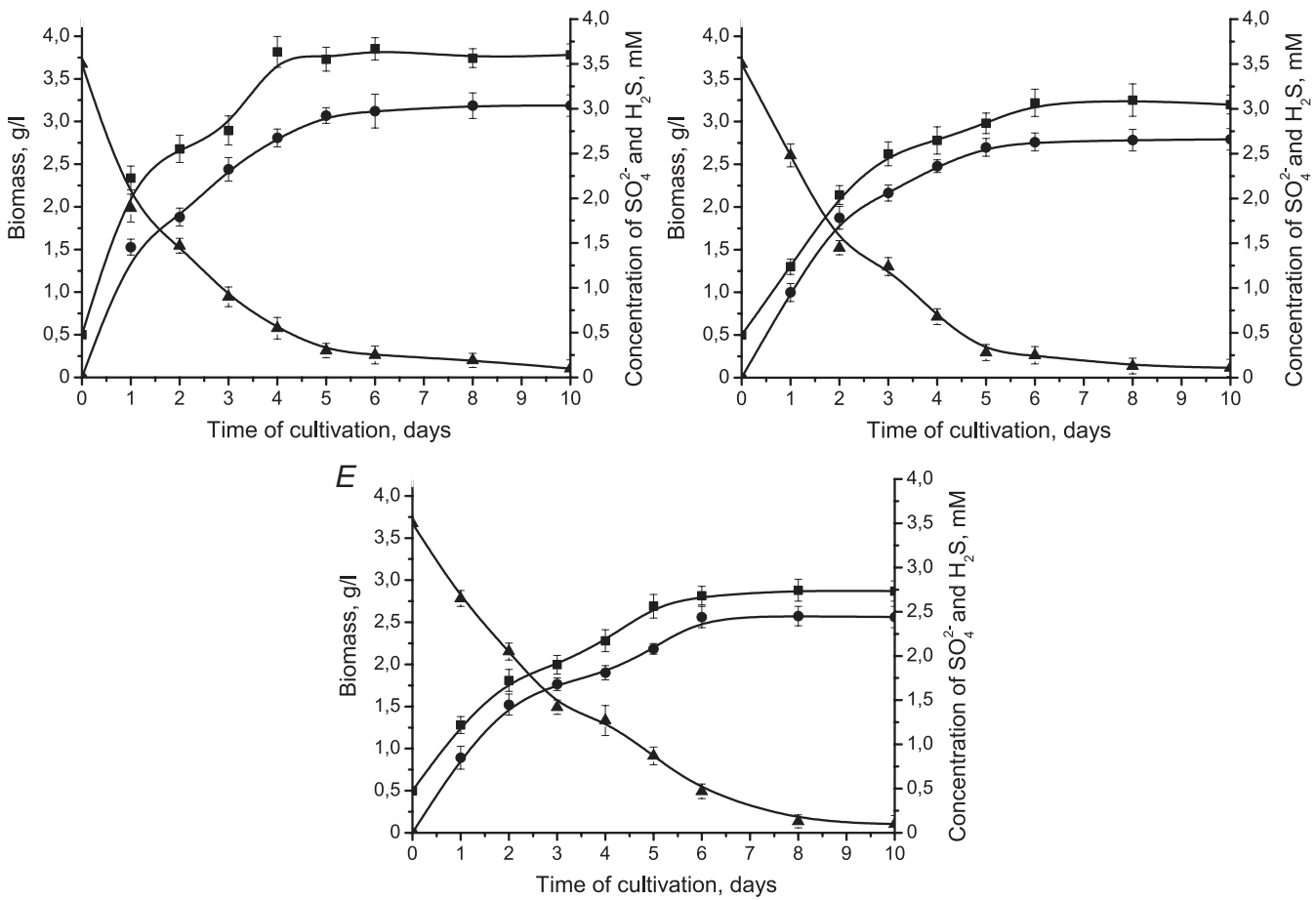

Fig. 3. The growth of different SRB strains, sulfate-ions usage and production of hydrogen sulfide by the strain: $A$ - SRB Vib-1; $B$ - SRB Vib-2; $C$ - SRB Vib-3; $D$ - SRB Rod-4; $E$ - SRB Rod-5; - - - biomass; $-\boldsymbol{\Delta}-\mathrm{SO}_{4}^{2-}$ concentration; $-\bullet-\mathrm{H}_{2} \mathrm{~S}$ concentration

Рис. 3. Ріст різних штамів СВБ, використання ними сульфатів і утворення гідроген сульфіду: $A-\mathrm{SRB}$ Vib-1; $B$ - SRB Vib-2; C - SRB Vib-3; D - SRB Rod-4; $E$ - SRB Rod-5; -匹- біомаса; трація $\mathrm{SO}_{4}^{2-} ;-\bullet-$ концентрація $\mathrm{H}_{2} \mathrm{~S}$

In process of dissimilatory sulfate reduction the sulfate-reducing bacteria produce hydrogen sulfide that accumulates in the environment and is toxic to the intestine cells 
$[2,17,20]$. The results of our study demonstrate that the obtained strains intensively produced hydrogen sulfide in the medium (see Fig. 3). Most of hydrogen sulfide (3.03, 3.12, $2.99 \mathrm{mM}$ ) was produced by SRB Vib-1, SRB Vib-2, SRB Vib-3 strains on the sixth day of cultivation, respectively. A little bit less intensively hydrogen sulfide was formed by SRB Rod-4 and SRB Rod-5 strains, and on the sixth day bacteria produced $2.63 \mathrm{mM}$ and $2.44 \mathrm{mM} \mathrm{H}_{2} \mathrm{~S}$, respectively.

The formation of hydrogen sulfide correlates with the usage of sulfates. The correlation coefficient $(r)$ between these processes equals -0.98 . We have found a reverse strong negative correlation between these processes.

Thus, SRB Vib-1, SRB Vib-2, SRB Vib-3, SRB Rod-4 and SRB Rod-5 strains perform intensively a dissimilatory sulfate reduction. The increased level of sulfates in the intestine can lead to intensive development of SRB and increasing of the concentration of hydrogen sulfide. Hydrogen sulfide is the main product of metabolism of these strains and can be accumulated in significant quantities in the environment. Increased concentration of this compound lead to the inhibition of intensity $\mathrm{H}_{2} \mathrm{~S}$ detoxification in human intestinal mucosa $[3,21]$. Therefore, hydrogen sulfide will also cause cytotoxic and potential carcinogenic effect, and the development of intestinal diseases [21]. It is known that hydrogen sulfide can also affect butyrate oxidation processes and, consequently, cause damage to the integrity of the epithelial barrier cells and inflammation of the coIon epithelium [19, 24, 25]. We isolated bacteria strains (SRB Vib-1, SRB Vib-2, SRB Vib-3) that belong to the Desulfovibrio genus. It is known from the literature that Desulfovibrio bacteria cause bloody diarrhea, weight loss and anorexia in animals and human. Under these conditions, epithelial hyperplasia, abscesses and inflammatory infiltrates can occur $[16,17]$.

An increased number of SRB in the gut can cause on acute inflammation of the mucous membranes increasing their permeability, the abdomen pain, frequent need for bowel movement, arthritis, discomfort and malaise [2, 13, 17].

In people with ulcerative colitis, members of the Desulfovibrio genus were dominant among all selected SRB $(55 \%)[6,7]$. Despite the fact that the number of SRB in sick people was small, the intensity of sulfate reduction was higher than in healthy people [7]. The SRB isolated from patients with the ulcerative colitis grew at low concentrations of sulfate. This is probably due to a composition of the medium intestine during colitis [3, 24].

Large number of the Desulfovibrio genus bacteria $\left(10^{6}-10^{7}\right.$ cells/gram) were found in the rectal biopsies taken from patients with colitis, as well as healthy controls. There were no differences between physiological and biochemical characteristics of these bacteria $[5,6,7]$. Probably, a disease can be caused by certain strains of microorganisms. In the development of disease pathogenesis, major factor is an excessive amount of hydrogen sulfide, which can not neutralized in the organism [24].

Our rstudy has shown that morphologically and physiologically different strains of isolated sulfate-reducing bacteria can grow intensively and produce hydrogen sulfide in the medium. Moreover, the isolated strains of vibrio-shaped (SRB Vib-1, SRB Vib-2, SRB Vib-3) can grow more intensively and use sulfates compared with strains of rodshaped bacteria (SRB Rod-4 and SRB Rod-5). Obviously, an intensive growth of vibrios in the intestine cause more damage to the intestinal cells than short rods. Presence and action of these microorganisms in human intestine to a great extent may be responsible for development of serious pathological states in gut and can be the pathogenic agent of the bowel disease. 
For identification of the genera and species of the described bacterial strains, more data of physiological and biochemical characteristics, as well as molecular genetic studies are necessary.

\section{CONCLUSIONS}

1. New strains of sulfate-reducing bacteria from human intestine were obtained. These strains form two types of black, round colonies with different size (large and small). These bacteria grow only in the presence of sulfate in the medium.

2. Selected strains of the sulfate-reducing bacteria intensively use sulfate ions and produce hydrogen sulfide in the medium of cultivation. Between these processes, a reverse strong negative correlation was established. The correlation coefficient $(r)$ is -0.98 . The vibrio-like strains (SRB Vib-1, SRB Vib-2, SRB Vib-3) can produce more hydrogen sulfide (up to $3.12 \mathrm{mM}$ ), compared with rod-shaped strains - SRB Rod-4 and SRB Rod-5 (up to $2.63 \mathrm{mM}$ ).

\section{NOTE OF ACKNOWLEDGEMENT}

The authors express their gratitude to Pavlo Kopnov, assistant professor of the Department of Histology, Cytology and Embryology at I.Horbachevsky Ternopil State Medical University for his help in conducting electron microscopy studies.

1. Babko A.K., P'yatnitsky I.V. Quantitative analysis. Kyiv: High School, 1974; 243 p.

2. Barton L.L., Hamilton W.A. Sulphate-reducing Bacteria. Environmental and Engineered. Cambridge University Press, 2007; 553 p.

3. Cummings J.H., Macfarlane G.T., Macfarlane S. Intestinal Bacteria and Ulcerative Colitis. Curr. Issues Intest. Microbiol, 2003; 4: 9-20.

4. Egorov N.S. A guide to practical training in microbiology. Pract. allowance. Moscow: Mosk. University, 1983; 215 p.

5. Gibson G.R., Cummings J.H., Macfarlane G.T. Growth and activities of sulphate-reducing bacteria in gut contents of health subjects and patients with ulcerative colitis. FEMS Microbiol. Ecol, 1991; 86: 103-112.

6. Gibson G.R., Macfarlane G.T., Cummings J.H. Sulphate-reducing bacteria and hydrogen metabolism in the human large intestine. Gut, 1993; 34: 437-439.

7. Gibson G.R., Macfarlane S., Macfarlane G.T. Metabolic interactions involving sulphate-reducing and methanogenic bacteria in the human large intestine. FEMS Microbiol. Ecol, 1993; 12: 117-125.

8. Holt J.G., Krieg N.R., Sneath P.H. et al. Bergey's Manual of Determinative Bacteriology. Ninth Edition. Moscow: Mir, 1997; 1: 426 p.

9. Isakova O.P., Tarasevych Yu.Yu., Yuzjuk Yu.I. Processing and visualization of data with the physical experiments by usage Origin package. Moscow: Book House «LIBKOM», 2009; 136 p.

10. Karavayko G.I., Kuznetsov S.I., Golomzik A.I. A role of microorganisms in a leaching of metals from ores. Moscow: Science, 1972; $248 \mathrm{p}$.

11. Kreshkov A.I. Fundamentals of analytical chemistry. Theoretical bases. Book First, ed. Fourth, revised. Moscow: Chemistry, 1976; 472 p.

12. Kushkevych I.V. Sulfate-reducing bacteria of the human intestine. I. Dissimilatory sulfate reduction. Sci. Int. J. Biological studies/Studia Biologica, 2012; 6(1): 149-180.

13. Kushkevych I.V. Sulfate-reducing bacteria of the human intestine. II. The role in the diseases development. Sci. Int. J. Biological studies/Studia Biologica, 2012; 6(2): 221-250.

14. Lakin G.F. Biometry. Moscow: High School, 1990; 352 p.

ISSN 1996-4536 • Біологічні Студії / Studia Biologica • 2012 • Том 6/№3 • C. 115-124 
15. Langendijk P.S., Kulik E.M., Sandmeier H. et al. Isolation of Desulfomicrobium orale sp. nov. and Desulfovibrio strain NY682, oral sulfate-reducing bacteria involved in human periodontal disease. J. Syst. Evol. Microbiol, 2001; 51(3): 1035-1044.

16. Loubinoux J., Bronowicji J.-P., Pereira I.A. et al. Sulphate-reducing bacteria in human feces and their association with inflammatory diseases. FEMS Microbiol. Ecol, 2002; 40: 107-112.

17. Loubinoux J., Mory F., Pereira I.A. et al. Bacteremia caused by a strain of Desulfovibrio related to the provisionally named Desulfovibrio fairfieldensis. J. Clin. Microbiol, 2000; 38: 931-934.

18. Macfarlane S., Dillon J.F. Microbial biofilms in the human gastrointestinal tract. J. Appl. Microbiol, 2007; 102: 1187-1196.

19. Macfarlane S., Hopkins M.J., Macfarlane G.T. Bacterial growth and metabolism on surfaces in the large intestine. Microb. Ecol. Health Dis, 2000; 2: 64-72.

20. Moore W.E.C., Johnson J.L., Holdeman L.V. Emendation of Bacteroidaceae and Butyrivibrio and descriptions of Desulfomonas gen. nov. and ten new species of the genera Desulfomonas, Butyrivibrio, Eubacterium, Clostridium and Ruminicoccus. Int. J. Syst. Bacteriol, 1976; 26: 238-252.

21. Pitcher M.C., Cummings J.H. Hydrogen sulphide: a bacterial toxin in ulcerative colitis? Gut, 1996; 39: 1-4.

22. Postgate J.R. The sulfate-reducing bacteria. 2nd ed. Cambridge: Cambridge Univ. Press, 1984; $199 \mathrm{p}$.

23. Reynolds E.S. The use of lead citrate at high $\mathrm{pH}$ as an electronopaque stain in electron microscopy. J. Cell Biol, 1963; 17: 208-212.

24. Rowan F.E., Docherty N.G., Coffey J.C. et al. Sulphate-reducing bacteria and hydrogen sulphide in the aetiology of ulcerative colitis. British Journal of Surgery, 2009; 96: 151-158.

25. Sekirov I., Russell S.L., Antunes L.C.M., Finlay B.B. Gut Microbiota in Health and Disease. Physiol. Rev, 2010; 90: 859-904.

26. Uikly B. Electron microscopy for beginners. Moscow: Publishing House of Mir, 1975; $314 \mathrm{p}$.

27. Zinkevich V.V., Beech I.B. Screening of sulfate-reducing bacteria in colonoscopy samples from healthy and colitic human gut mucosa. FEMS Microbiol. Ecol, 2000; 34: 147-155.

\section{РІСТ РІЗНИХ ШТАМІВ СУЛЬФАТВІДНОВЛЮВАЛЬНИХ БАКТЕРІЙ ТОВСТОГО КИШЕЧНИКА ЛЮДИНИ}

\section{I. В. Кушкевич', О. М. Мороз ${ }^{2}$}

1 Львівський національний медичний університет імені Данила Галицького вул. Пекарська, 69, Львів 79010, Україна

${ }^{2}$ Львівський національний університет імені Івана Франка вул. Грушевського, 4, Львів 79005, Україна e-mail: ivan.kushkevych@gmail.com

Виділено нові штами сульфатвідновлювальних бактерій кишечника людини. Ці бактерії були вібріоподібної (штами SRB Vib-1, SRB Vib-2, SRB Vib-3) та паличкоподібної (штами SRB Rod-4 i SRB Rod-5) форм. Досліджено ріст штамів цих бактерій, використання ними сульфатів і утворення гідроген сульфріду. Сульфатвідновлювальні бактерії штамів SRB Vib-1, SRB Vib-2 i SRB Vib-3 більш інтенсивно нагромаджують біомасу, порівняно зі штамами SRB Rod-4 i SRB Rod-5. Штами бактерій SRB Vib-1 та SRB Vib-2 росли найбільш інтенсивно. Найбільша біомаса (3,8 г/л) нагромаджувалася на третю добу культивування, після чого бактерії переходили у стаціонарну фазу росту. Бактерії штаму SRB Vib-3 нагромаджують біомасу 2,89 г/л на третю добу 
культивування. Найбільший рівень біомаси (від 2,59 до 3,25 г/л) штамів бактерій SRB Rod-4 i SRB Rod-5 спостерігали на восьму добу культивування. Виділені сульфатвідновлювальні бактерії інтенсивно використовують сульфат-іони й утворюють гідроген сульфід. Встановлено, що штами SRB Vib-1, SRB Vib-2 i SRB Vib-3 продукують від 2,99 мМ до 3,12 мМ гідроген сульфіду в середовище. За наявності сульфатів штами сульфатвідновлювальних бактерій SRB Rod-4 i SRB Rod-5 менш інтенсивно використовують сульфат-іони й утворюють гідроген сульфід.

Ключові слова: сульфатвідновлювальні бактерії, Desulfovibrio, Desulfomicrobium, сульфати, гідроген сульфід, захворювання кишечника, виразкові коліти, кишкові мікробіоценози.

\section{РОСТ РАЗНЫХ ШТАММОВ СУЛЬФАТВОССТАНАВЛИВАЮЩИХ БАКТЕРИЙ ТОЛСТОГО КИШЕЧНИКА ЧЕЛОВЕКА}

И. В. Кушкевич'

1 Львовский национальный медицинский университет имени Даниила Галицкого, ул. Пекарская, 69, Львов 79010, Украина

${ }^{2}$ Львовский национальный университет имени Ивана Франко, ул. Грушевского, 4, Львов 79005, Украина e-mail: ivan.kushkevych@gmail.com

Выделены новые штаммы сульфатвосстанавливающих бактерий кишечника человека. Эти бактерии были вибриовидной (штаммы SRB Vib-1, SRB Vib-2, SRB Vib-3) и палочковидной (штаммы SRB Rod-4 и SRB Rod-5) фоорм. Исследованы рост этих штаммов бактерий, использование ими сульфатов и образование гидроген сульфида. Сульфатвосстанавливающие бактерии штаммов SRB Vib-1, SRB Vib-2 и SRB Vib-3 более интенсивно накапливают биомассу, по сравнению со штаммами SRB Rod-4 и SRB Rod-5. Штаммы бактерий SRB Vib-1 и SRB Vib-2 pocли наиболее интенсивно. Наибольшая биомасса (3,8 г/л) накапливалась на третьи сутки культивирования, после чего бактерии переходили в стационарную фазу роста. Бактерии штамма SRB Vib-3 накапливают биомассу 2,89 г/л на третьи сутки культивирования. Максимальная биомасса (от 2,59 до 3,25 г/л) штаммов бактерий SRB Rod-4 и SRB Rod-5 наблюдалась на восьмые сутки культивирования. Выделенные сульфатвосстанавливающие бактерии интенсивно используют сульфатионы и образуют сероводород. Установлено, что штаммы SRB Vib-1, SRB Vib-2 и SRB Vib-3 производят от 2,99 мМ до 3,12 мМ сероводорода в среду. При наличии сульфатов штаммы сульфатвосстанавливающих бактерий SRB Rod-4 и SRB Rod5 менее интенсивно используют сульфат-ионы и образуют сероводород.

Ключевые слова: сульфатвосстанавливающие бактерии, Desulfovibrio, Desulfomicrobium, сульфаты, сероводород, заболевания кишечника, язвенные колиты, кишечные микробиоценозы.

Одержано: 18.10.2012

ISSN 1996-4536 • Біологічні Студії / Studia Biologica • 2012 • Том 6/№3 • С. 115-124 